\title{
ANALYSIS OF SEA WATER POLLUTION IN COASTAL MARINE DISTRICT TUBAN TO THE QUALITY STANDARDS OF SEA WATER WITH USING STORET METHOD
}

\author{
Perdana Ixbal Spanton $\mathbf{M}^{\mathbf{1}}$, Abdul Azis Saputra ${ }^{2}$ \\ ${ }^{1}$ PGRI University of Ronggolawe, Tuban \\ ${ }^{2}$ Marine Science Studies Program, PGRI University of Ronggolawe, Tuban \\ ${ }^{*}$ Corresponding author e-mail: ixbal.spanton@gmail.com
}

Submitted: 28 February 2017 / Revised: 28 February 2017 / Accepted: 26 April 2017

http://doi.org/10.21107/jk.v10i1.2671

\begin{abstract}
The sea water is a component that interacts with the terrestrial environment, where sewage from the land will lead to the sea. Waste containing these pollutants will enter into coastal waters and marine ecosystems. Partially soluble in water, partially sinks to the bottom and was concentrated sediment, and partly into the body tissues of marine organisms. This study was conducted to determine the level of pollution of sea water on the coast in the district of Tuban. This research was conducted in the Coastal Water Tuban, East Java. The main material used in research on Analysis of Water Pollution in Coastal Sea on Tuban. The method used in this research is using storet method and compared to the quality standards of the Environment Decree No. 51 in 2004. Based on the analysis of testing at five sampling point's seawater around Bodies Tuban, obtained by sea water quality measurement results either in physics, chemistry, and microbiology varied. The level of pollution of sea water around Coastal Tuban obtained by using Storet Method average value of analysis is -4.2 included in class $B$ are lightly blackened, while using values obtained Pollution Index average pollution index of 3.60 is included in the category lightly blackened.
\end{abstract}

Keywords: Analysis of the pollution level of seawater on the coast in Tuban, Quality Standards of Sea Water, Storet Method.

\section{INTRODUCTION}

The territorial waters of the coastal one highly productive ecosystems in marine waters. However behind its potential, development usually also mainly concentrated in coastal areas, so that often creates a negative impact on the potential of these resources, human activity in exploiting natural resources on it, such as industry, agriculture, fisheries, mining, navigation, and tourism are often multiple overlap, so it is not uncommon benefit or value to the ecosystem will be down. These activities often produce waste pollutants harmful to the marine waters life of or destroy fishes habitat in coastal areas. The impact on coastal communities, fishermen and farmers lose fields or jobs.

Miller (2004), defines that the pollution is spreading the addition of air, water and soil, or food that endangers the health, resilience or activities of humans or other living organisms. Meanwhile, based on Law No. 23, 1997 (Anonymous, 2006), pollution is the entry or the entry living creatures, substances, energy or other components into the environment with human activities so that quality decreases to a certain level which causes the environment not to work as intended.

In this research, researchers to test the levels of quality of coastal waters are among others: physical parameters, temperature and TSS, chemical parameters, $\mathrm{pH}$, salinity, $\mathrm{DO}, \mathrm{BOD}$, COD, ammonia and Heavy Metal, while the biological parameter that is Plankton. The Selection of test parameters done to determine the level of contamination of coastal areas in the district of Tuban.

The research analyzes the level of pollution of sea water in the coastal district of Tuban. 
The quality standard seawater using storet methods expected to provide information about the level of Water Pollution of the Sea in Coastal Tuban, especially those located near where the fish auction place Cross, Island Temple Shrine Tuban, Jenu New Terminal, Cement Port Tambak Boyo, and the fish auction place Feather Bancar. The thing to do is check the TSS, ammonia, DO, BOD, COD, Iron, Lead and Plankton to do in Water Quality Laboratory Faculty of Fisheries and Marine, UNIROW Tuban.

\section{MATERIALS AND METHODS}

Table 1. The materials used in this research

\begin{tabular}{|c|l|l|}
\hline No. & The Ingredient Name & \multicolumn{1}{c|}{ Functions } \\
\hline 1 & Sea Water & As Materials Research \\
\hline 2 & Distilled Water & As Materials Cleaning Tools \\
\hline 3 & Sterile Distilled Water & As Materials Sample Diluent \\
\hline
\end{tabular}

Table 2. The tools of used in this research

\begin{tabular}{|c|l|l|}
\hline No. & \multicolumn{1}{|c|}{ Tools } & \multicolumn{1}{c|}{ Functions } \\
\hline 1 & Bottle & As a sample of sea water \\
\hline 2 & Secsidisk & As brightness of measuring instrument \\
\hline 3 & pH pen / pH indikator & As a Ph of measuring instrument \\
\hline 4 & Thermometer & As a temperature of measuring instrument \\
\hline 5 & Refrakto & As a salinity of measuring instrument \\
\hline 6 & Measuring Glass & As a sample of measuring instrument \\
\hline 7 & Stationary & As a wroted of instrument \\
\hline 8 & Camera & As a documentation of instrument \\
\hline
\end{tabular}

1. Sampling of Seawater

Sampling of sea water, NFPA 0624121991 regarding water quality sampling methods. The steps are: Setting up a sampling tools in the form of sample bottles that had been cleaned beforehand. Sampling at a depth of 1 meter from the surface. Than carried out at a distance of 10$20 \mathrm{~m}$ from the shore, in this research a sample taken at the water surface. First draw a sample of water used to rinse sample bottles with a sample to be taken three times.

2. Sampling for examination of Dissolved Oxygen (DO)

a. Prepare a clean plastic bottle that has a volume of $600 \mathrm{ml}$ and equipped with a lid sharpening.

b. Dipping bottle carefully into the water with the bottle mouth position in the direction of the flow of water, so the water into the bottle with calm.

c. The Bottle filling to the brim to avoid the occurrence of turbulence and air bubbles over charging, then bottled in the cap

3. Sampling For Ammonia Inspection a. Prepare a clean plastic bottle that has a volume of $600 \mathrm{ml}$ and equipped with a lid sharpening.

b. Dipping bottle carefully into the water with a bottle mouth position in the direction of the flow of water, so the water into a bottle with calm.

c. Filled a Bottle to the brim to avoid occurrence of turbulence and air bubbles during filling, then bottled in the cap.

4. Sampling For Inspection (BOD)

a. Setting up a glass bottle of dark / light having a volume of $600 \mathrm{ml}$ and equipped with a lid sharpening

b. Dipping bottle carefully into the water with a bottle mouth position in the direction of the flow of water, so the water into a bottle with calm.

c. Filled a Bottle to the brim to avoid occurrence of turbulence and air bubbles during filling, then bottled in the cap.

d. Silence diving 5 days after it had analyzed.

5. Sampling For Inspection (COD) 
a. Setting up a glass bottle of dark / light having a volume of $600 \mathrm{ml}$ and equipped with a lid sharpening

b. Dipping bottle carefully into the water with a bottle mouth position in the direction of the flow of water, so the water into a bottle with calm.

c. Filled a Bottle to the brim to avoid occurrence of turbulence and air bubbles during filling, then bottled in the cap.

6. Sampling For Heavy Metal Inspection

a. Setting up a glass bottle of dark / light having a volume of $600 \mathrm{ml}$ and equipped with a lid sharpening

b. Dipping bottle carefully into the water with a bottle mouth position in the direction of the flow of water, so the water into a bottle with calm.

c. Filled a Bottle to the brim to avoid occurrence of turbulence and air bubbles during filling, then bottled in the cap.

7. Examination of Sea Water Samples

a. $\mathrm{Ph}$

Measurement of $\mathrm{pH}$ using a $\mathrm{pH}$ meter. The use of a $\mathrm{pH}$ meter immersed in the water sample can be directly seen measurement results.

b. Salinity

Salinity measurements using a refractometer. Using a refractometer with dripping seawater samples on glass and then see the boundary between the colors blue and white at the boundary meeting of two of these colors show the results of measurements of salinity.

c. Temperature

Measurement of temperature using a thermometer. At the end there is a hole termometar to be associated with a rope so that when the thermometer measurements are not in direct contact with your hands because it can affect the measurement results, when measuring the position of the thermometer turned toward the sun as it can affect the measurement results.
Used of direct thermometer dipped in water and immediately read the results seen red color border wait until it stops at number show the measurement results.

d. A brightness

A brightness measurement using a tool called secchidisk. Secchidisk to be put into the water slowly and see a color of the dish until no visible or vague there look at how much added. The units of measure the brightness usually use centimeters (cm).

Whereas examination of water quality parameters of chemical, biological, and dissolved metals carried exsitu (at the laboratory). The water samples were used for measurements previously done exsitu preservation with the way samples were stored in a cool box (low temperature) and immediately taken to the laboratory for the quality of water taken unchanged from it is original nature. Parameters measured exsitu is Ammonia, $\mathrm{BOD}$, COD, Lead $\mathrm{Pb}$ and Fe Iron.

Location of the research (sampling) is carried out in the waters around the industry, the fish auction place, and Coast Tourism. Location purposive sampling method is determining the location based on their specific purpose and in accordance with the consideration of the researchers themselves that represent the population (Arikunto, 2006), and is done by tracking the use of GPS (General Position Sample) at location research it is waters Tuban Regency East Java Province. The tracking of results taken five points to test the sea water quality analysis. There for it, the determination of the research station have been selected based for the type of activities on the beach of Tuban. There are five stations were set for sampling seawater and taken at what point in each region commissioned the test sample.

1. Point 1: The station is located in the area of the fish auction place of Palang at Palang Tuban districts. The station is a place reliance fishing vessels and fish markets. Cross fish auction place located at coordinates $6^{\circ} \mathrm{S} 112^{\circ} \mathrm{E}$ 54'4.0104" 8'34.9944". 
2. Point 2: The station is located in the area at pagoda Tuban beach tourism, besides there are many settlements and fishing activities. pagoda beach tourist spot located at coordinates $6^{\circ} \mathrm{S} 112^{\circ} \mathrm{E}$ 52'44.9544" 2'38.6592".

3. Point 3: The station is located in the area of new terminal at District Jenu Tuban including tourist areas and on the other close to the settlement as well estuaries. New Terminal is located at coordinates $6^{\circ} \mathrm{S} 112^{\circ} \mathrm{E} \mathrm{51'26.8056"1'32.9736"}$

4. Point 4: This station is located in an industrial park area Tambakboyo Port
Gresik cement District of Tuban including industrial areas and waste disposal area that caused by the number of cruise activities to become the source of the content of heavy metals in the waters mentioned. Coordinates S $6{ }^{\circ}$ 46'50. 5596" E 111 ०53'46.1724"

5. Point 5: This station is located in the area where the fish auction feather Bancar Tuban districts. The station is a place reliance fishing vessels and fish markets. 6 ○ S $111^{\circ}$ E 46'10.7976" 43'8.5476".

Table 3. Sea Water Quality Standards

\begin{tabular}{|c|c|c|c|c|}
\hline No & Parameter & Unit & Requirements & $\begin{array}{c}\text { Test of } \\
\text { Techniques }\end{array}$ \\
\hline & Physics & & & \\
\hline 1. & Smell & - & Not smell & Organoleptik \\
\hline 2. & Flavor & - & normal & Organoleptik \\
\hline 3. & Colour & TCU & $\max .15$ & Spektrofotometri \\
\hline 4. & $\begin{array}{l}\text { Total Dissolved Solids } \\
\text { (TDS) }\end{array}$ & $\mathrm{mg} / \mathrm{l}$ & $\max .1000$ & Gravimetri \\
\hline 5. & Turbidity & NTU & $\max .5$ & Spektrofotometri \\
\hline \multirow[t]{2}{*}{6.} & Temperature & ${ }^{\circ} \mathrm{C}$ & $\begin{array}{l}\text { Air Temperature } \\
3^{\circ} \mathrm{C}\end{array}$ & Termometer \\
\hline & Chemistry & & & \\
\hline 7. & Iron (Fe) & $\mathrm{mg} / \mathrm{l}$ & $\max 0.3$ & AAS \\
\hline 8. & Hardness as $\mathrm{CaCO}_{3}$ & $\mathrm{mg} / \mathrm{l}$ & $\max .500$ & Titrimetri \\
\hline 9. & Chloride $(\mathrm{Cl})$ & $\mathrm{mg} / \mathrm{l}$ & $\max 250$ & Argentometri \\
\hline 10. & Manganese (Mn) & $\mathrm{mg} / \mathrm{l}$ & $\max 0.1$ & AAS \\
\hline 11. & $\mathrm{pH}$ & - & $6,5-8.5$ & $\mathrm{pH}$ meter \\
\hline 12. & Zinc (Zn) & $\mathrm{mg} / \mathrm{l}$ & $\max .8$ & AAS \\
\hline 13. & Sulphate $\left(\mathrm{SO}_{4}\right)$ & $\mathrm{mg} / \mathrm{l}$ & $\max 250$ & Spektrofotometri \\
\hline 14. & Copper (Cu) & $\mathrm{mg} / \mathrm{l}$ & $\max .1$ & AAS \\
\hline 15. & Chlorine $\left(\mathrm{Cl}_{2}\right)$ & $\mathrm{mg} / \mathrm{l}$ & $\max .5$ & Titrimetri \\
\hline \multirow[t]{2}{*}{16.} & Ammonium $\left(\mathrm{NH}_{3}\right)$ & $\mathrm{mg} / \mathrm{l}$ & $\max 0.3$ & $\begin{array}{l}\text { Spektrofotometri } \\
\text { (Nesler) }\end{array}$ \\
\hline & Inorganic Chemistry & & & \\
\hline 17. & Arsenic (As) & $\mathrm{mg} / \mathrm{l}$ & $\max .0 .01$ & AAS \\
\hline 18. & Fluorida $(\mathrm{F})$ & $\mathrm{mg} / \mathrm{l}$ & $\max 1.5$ & Spektrofotometri \\
\hline 19. & $\begin{array}{l}\text { Chrome heksavalen } \\
\left(\mathrm{Cr}^{6+}\right)\end{array}$ & $\mathrm{mg} / \mathrm{l}$ & $\max 0.05$ & AAS \\
\hline 20. & Cadmium (Cd) & $\mathrm{mg} / \mathrm{l}$ & $\max .0 .003$ & AAS \\
\hline 21. & Nitrate $\left(\mathrm{NO}_{3}\right)$ & $\mathrm{mg} / \mathrm{l}$ & $\max 50$ & $\begin{array}{l}\text { Spektrofotometri } \\
\text { (Brusin) }\end{array}$ \\
\hline 22. & Nitrites $\left(\mathrm{NO}_{2}\right)$ & $\mathrm{mg} / \mathrm{l}$ & $\max 3$ & $\begin{array}{l}\text { Spektrofotometri } \\
\text { (NED) }\end{array}$ \\
\hline 23. & Cyanide $(\mathrm{CN})$ & $\mathrm{mg} / \mathrm{l}$ & $\max 0.07$ & Destilasi \\
\hline 24. & Laed $(\mathrm{Pb})$ & $\mathrm{mg} / \mathrm{l}$ & $\max 0.3$ & AAS \\
\hline \multirow[t]{2}{*}{25.} & Mercury $(\mathrm{Hg})$ & $\mathrm{mg} / \mathrm{l}$ & $\max 0.001$ & AAS \\
\hline & Microbiology & & & \\
\hline 24. & Plankton & Sel/100ml & not bloom & MPN \\
\hline 25. & Total Coliform Bacteria & APM/100ml & Negative & MPN \\
\hline
\end{tabular}

Source : KepMenKes No. 51/MENKES/SK/VII/2004. 
RESULTS AND DISCUSSION

\section{Storet Method}

The research is, data analysis of the quality of sea water around Coastal Tuban will be compared with the quality standards of the Environment Decree No. 51 of 2004 on marine water quality standard for marine biotas. If the test of results do not exceed the quality standard parameter then given a score of 0 , while the value of the test parameters have exceeded the quality standard in terms of the measurement results $>$ quality standards, it is given a score according to Table 4 . The total score Storet method relies on a number of parameters that have a value test exceeds the specified threshold, the more of parameter values that exceed the threshold are allowed then the value will be even greater score.

Table 4. Sea Water Quality Measurement Results of Water Tuban district.

\begin{tabular}{|c|c|c|c|c|c|c|c|c|}
\hline \multirow[t]{2}{*}{ NO } & \multirow{2}{*}{\begin{tabular}{|c|} 
Parameter \\
Fisika \\
\end{tabular}} & \multirow[t]{2}{*}{ Satuan } & \multirow{2}{*}{$\begin{array}{c}\text { Batas Maks/Min } \\
\text { yang dipe rbolehkan }\end{array}$} & \multicolumn{2}{|c|}{ Lokasi1 Lokasi 2} & Lokasi3 & \multirow[t]{2}{*}{ kasi 4} & \multirow[t]{2}{*}{ Lokasi 5} \\
\hline & & & & & & & & \\
\hline 1 & temperatur & $\mathrm{C}$ & $(-)$ & 31,6 & 29,8 & 31,5 & 31,4 & 29,1 \\
\hline \multirow[t]{2}{*}{2} & TTS & $\mathrm{ppm}$ & 20 & 331 & 381 & 338 & 256 & 450 \\
\hline & Kimia & & & & & & & \\
\hline 3 & $\mathrm{pH}$ & $(-)$ & $6,5-8,5$ & 6,8 & 7,3 & 7,1 & 7,4 & 7,2 \\
\hline 4 & Salinitas & promil & $\left(\_\right)$ & 27 & 26 & 8 & 28 & 28 \\
\hline 5 & DO & ppm & $>5$ & 2,9 & 1,9 & 1,4 & 2,5 & 2,0 \\
\hline 6 & BOD & ppm & 20 & 2 & 2,4 & 4 & 2,3 & 3,1 \\
\hline 7 & COD & $\mathrm{ppm}$ & 10 & 1082.67 & 1179.33 & 1256 & 1282.67 & 1132.67 \\
\hline 8 & Amunia & Ppm & 0,3 & 0.6459 & 0.3955 & 0.3564 & 0.0767 & 0.1033 \\
\hline 9 & Timbal & Ppm & 0,3 & - & - & - & - & - \\
\hline \multirow[t]{2}{*}{10} & $\mathrm{Fe}$ & Ppm & 0,3 & 0,05 & 0,2 & 0,1 & 0,05 & 0,05 \\
\hline & Biologi & & & & & & & \\
\hline 11 & Plankton & $\mathrm{Sel} / 100 \mathrm{ml}$ & 100 & 0.825 & 0.737 & 0.869 & 0.774 & 0.683 \\
\hline
\end{tabular}

Informations : $\quad$ Values of exceed the maximum threshold. 
Table 5. Results of Data Analysis Sea water Quality Measurement with Storet Method.

\begin{tabular}{|c|c|c|c|c|c|c|c|c|c|c|c|c|c|}
\hline No & Parameter & Satuan & \begin{tabular}{|c|} 
Batas \\
Maks/Min \\
Yang di \\
Perbolehkan \\
\end{tabular} & Lokasi1 & Lokasi 2 & Lokasi 3 & Lokasi 4 & Lokasi 5 & \multicolumn{5}{|c|}{ Skor } \\
\hline & Fisika & & & & & & & & 1 & 2 & 3 & 4 & 5 \\
\hline 1 & Temperatur & $(-)$ & $(-)$ & 31,6 & 29,8 & 31,5 & 31,4 & 29,1 & 0 & 0 & 0 & 0 & 0 \\
\hline \multirow[t]{2}{*}{2} & TSS & ppm & 20 & 331 & 381 & 338 & 256 & 450 & -1 & -1 & -1 & -1 & -1 \\
\hline & Kimia & & & & & & & & & & & & \\
\hline 3 & $\mathrm{pH}$ & $(-)$ & $6,5-8,5$ & 6,8 & 7,3 & 7,1 & 7,4 & 7,2 & 0 & 0 & 0 & 0 & 0 \\
\hline 4 & Salinitas & promil & $(-)$ & 27 & 26 & 8 & 28 & 28 & 0 & 0 & 0 & 0 & 0 \\
\hline 5 & $\mathrm{DO}$ & $\mathrm{ppm}$ & $>5$ & 2,9 & 1,9 & 1,4 & 2,5 & 2,0 & 0 & 0 & 0 & 0 & 0 \\
\hline 6 & BOD & ppm & 20 & 2 & 2,4 & 4 & 2,3 & 3,1 & 0 & 0 & 0 & 0 & 0 \\
\hline 7 & $\mathrm{COD}$ & $\mathrm{ppm}$ & 10 & 1082.67 & 1179.33 & 1256 & 1282.67 & 1132.67 & -2 & -2 & -2 & -2 & -2 \\
\hline 8 & Amunia & & 0,3 & 0.6459 & 0.3955 & 0.3564 & 0.0767 & 0.1033 & -2 & -2 & -2 & 0 & 0 \\
\hline 9 & Timbal & ppm & 0,3 & - & - & - & - & - & 0 & 0 & 0 & 0 & 0 \\
\hline \multirow[t]{2}{*}{10} & $\mathrm{Fe}$ & $\mathrm{ppm}$ & 0,3 & 0,05 & 0,2 & 0,1 & 0,05 & 0,05 & 0 & 0 & 0 & 0 & 0 \\
\hline & Biologi & & & & & & & & & & & & \\
\hline 11 & Plankton & $\mathrm{Sel} / 100 \mathrm{ml}$ & 100 & 0.825 & 0.737 & 0.869 & 0,774 & 0.683 & 0 & 0 & 0 & 0 & 0 \\
\hline & & & & & & & & & & & & & \\
\hline \multicolumn{9}{|c|}{ Jumlah Skor } & -5 & -5 & -5 & -3 & -3 \\
\hline \multicolumn{9}{|c|}{ Rata-Rata } & & & -4.2 & & \\
\hline
\end{tabular}

Informations : $\quad$ Value exceeding the threshold of maximum / minimum

Value Index score of Storet

Seawater sampling points has a score ranging from a score of -3 to -5 . Point 1,2 , and 3 have the highest score because the value of the sample points 1,2 , and 3 more parameters that exceed the quality standard limits. Based on the results of data analysis using Storet refers to the quality standards of the Environment Decree No. 51 of 2004 on marine water quality standard for marine life, sea water around Coastal Tuban obtain a score of -4.2 , then according to the analysis method Storet sea water around Coastal Tuban classified in class B (good) or lightly blackened if destined for Marine biotas.

\section{Pollution Index Method}

Pollution Index requires the average value of the total value that is parameter Ci / Lij. Value
$\mathrm{Ci} / \mathrm{Lij}$ must include the maximum value, this value is not meaningful if $\mathrm{Ci} / \mathrm{Lij}-$ value $>1$ benchmark of water pollution if the value $(\mathrm{Ci} /$ $\mathrm{LijR})$ or $(\mathrm{Ci} / \mathrm{LijM})$ is greater than 1.0 , if the value of $(\mathrm{Ci} / \mathrm{LijR})$ or $(\mathrm{Ci} / \mathrm{LijM})$ getting bigger, then the level of pollution of a water body will be greater to.

The results of analysis seawater samples obtained Tuban Coastal value comparison between the measurement results $(\mathrm{Ci})$ with the quality standards of the Environment Decree No. 51 of 2004 on seawater quality standard for marine biotas (Lij), it can be determined the value $\mathrm{Ci}$ / $\mathrm{Lij}$ each parameter in seawater samples tested. 
Table 6. Results of Data Analysis Pollution Index Method

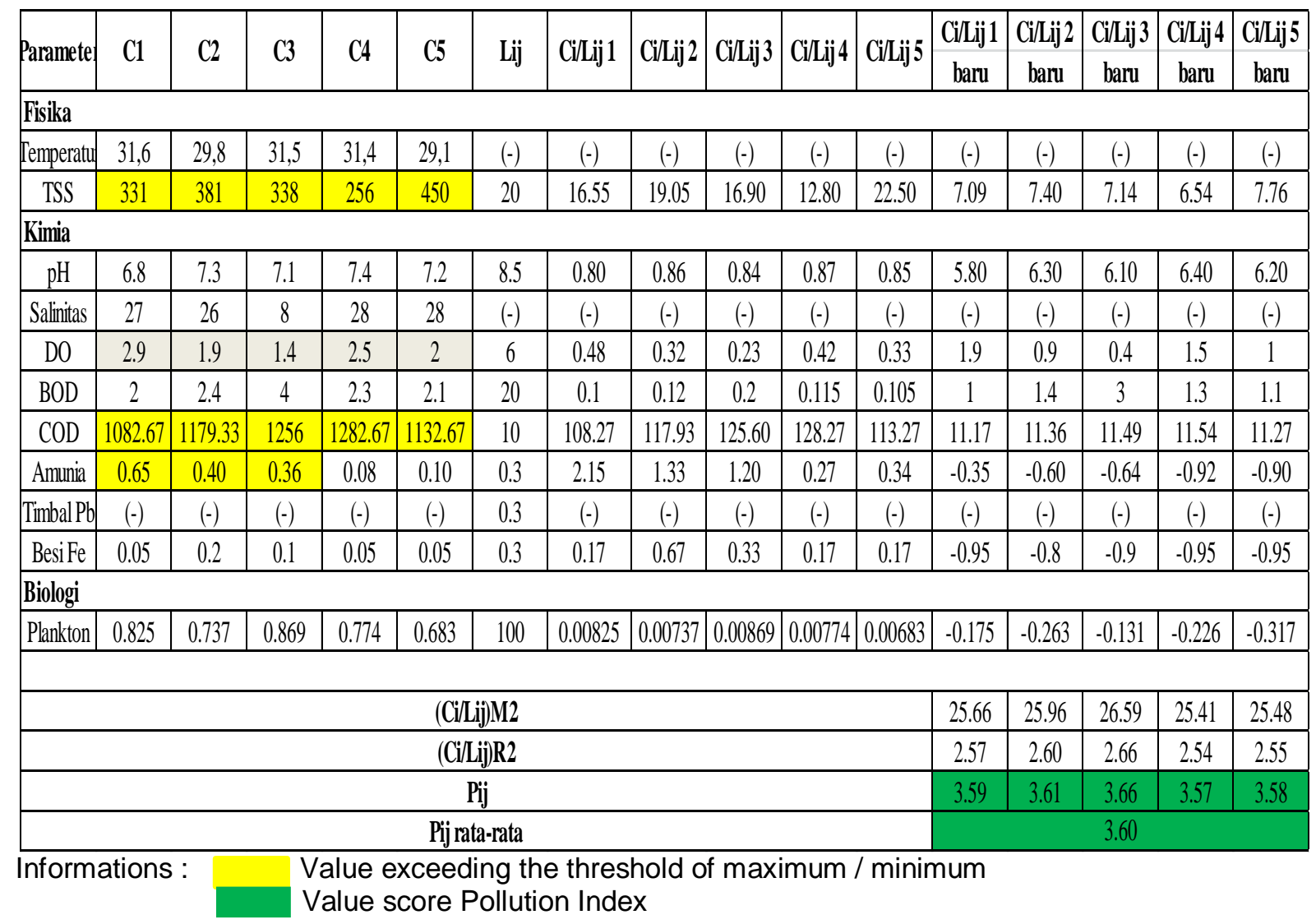

Based on the results of data analysis using Pollution Index, the result is different in each of the sampling seawater points. Coastal seawater pollution index Tuban obtain a score average (PIR) 3.60, with reference to the quality standards of the Environment Decree No. 51 of 2004 on seawater quality standard for marine lifes can be summed seawater around Tuban coastal Beach classified in categories lightly blackened intended for marine biotas. Based on the table 8 may be made Pollution Index Method diagram in Figure 3 below:

\section{Indeks Pencemaran}

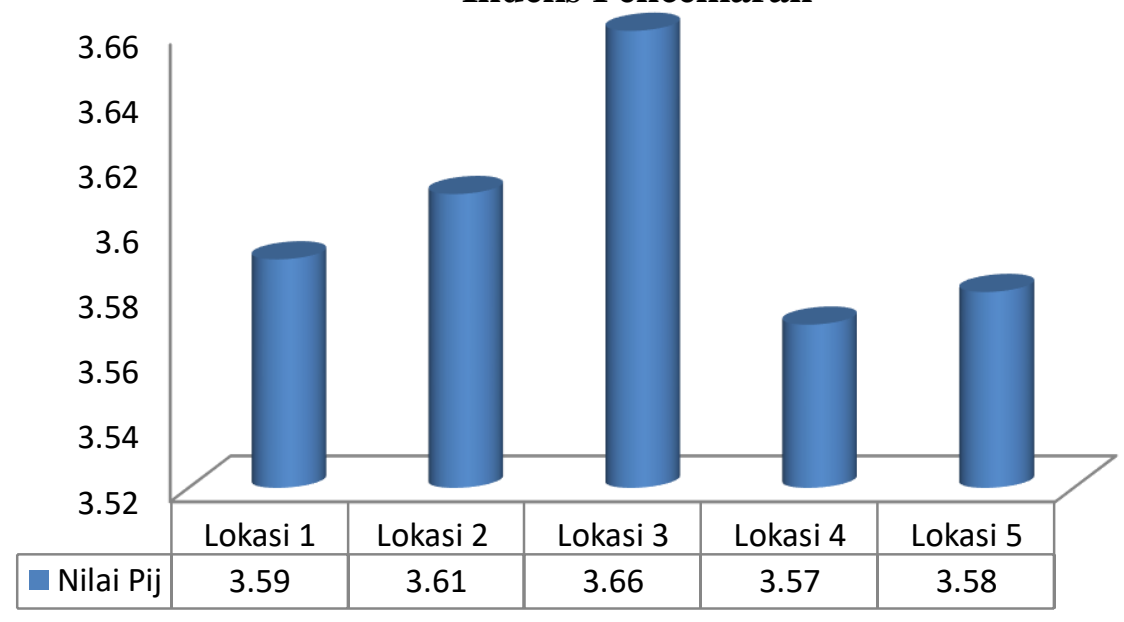

Picture 1. Quality Water Score Pollution Index Method 
Based on the results of data analysis using Pollution Index, the result is different in each of the sampling seawater points. Coastal seawater pollution index Tuban obtain a score average (PIR) 3.60, with reference to the quality standards of the Environment Decree No. 51 of 2004 on seawater quality standard for marine lifes can be summed seawater around Tuban coastal Beach classified in categories lightly blackened intended for marine lifes.

From the data analysis can be described some discussion, namely, from 5 samples of sea water taken at 5 points scattered around Coastal Tuban showed seawater quality measurements that is vary each parameter, at some point the decision shows fluctuations. Based on quality standards decree LH No 51 of 2004 the designation of marine lifes, the parameters that exceed the threshold of which total coliform in point 5 , the parameters of TSS, DO, COD and Ammonia in five sampling points, high $\mathrm{COD}$ and $\mathrm{DO}$ in water samples caused by activities of coastal communities that include disposal of garbage in the seawater to the river aquaculture waste disposal, waste disposal of the fish auction. As for the total coliform parameter values that exceed the highest quality standards are at the point of 1,2 , and 3 , this is due to location along two sampling points close to the estuary zone. There is sewage from the community, and cultivating, which flows down to the sea. Because that is where activities such as bathing, washing, and waste water, so that the value of total coliform exceeded the quality standard. The low value of the DO indicates the number of microorganisms that use oxygen to decompose organic matter contained in water. DO low value is very dangerous for marine lifes because it would reduce the supply of oxygen and inhibit the growth of marine organisms.

\section{CONCLUSION}

1. Based on the analysis of testing at five sampling point's seawater around Tuban Beach, obtained to the seawater quality measurement results either in physics, chemistry, and microbiology varied. The quality of sea water in physics which includes temperature has an average value of the temperature measurement $30,68^{\circ} \mathrm{C}$. not exceed the quality standards of the Environment Decree No. 51 of 2004 on sea water quality standard for marine biotas. While TSS Total Suspended Solid $351.2 \mathrm{ppm}$ exceed the quality standards. Results of testing chemical parameters with an average value of 23.4 PROMIL include salinity, BOD $14.8 \mathrm{ppm}$, pH of 7.16, qualify the quality standards set. In contrast to the value of ammonia ineligible quality standards at some point is the point 1,2 and 3 with a value of $0.65 \mathrm{ppm}, 0.40 \mathrm{ppm}$, 0.36 ppm.dan COD with the average value of $1186.67 \mathrm{ppm}$. As for microbiological parameters that meet the quality standards plankton Minister of Environment Decree No. 51 of 2004 on marine water quality standard for marine biotas.

2. Sources of pollutants that cause deterioration of seawater quality around the sea comes from the Tuban Beach, ship waste, waste from fish auctions, garbage disposal waste to the sea and residential areas in the Coastal Tuban.

3. The level of pollution sea water around Coastal Tuban using Storet method obtained an average value of analysis is -4.2 included in class B are lightly blackened, while using values obtained Pollution Index average pollution index of 3.60 , including in the category of lightly blackened.

\section{REFERENCES}

Anonymous, (2011). http: // repository. usu. Air conditioning. id / bitstream / 123456789/25767/4 / Chapter\% 20ll.pdf.accessed on July 5, 2015.

Anonymous. (2006). Pelaksanaan Gerakan Clean Coastal and Marine. Directorate General of Coastal and Small Islands Ministry of Marine Affairs and Fisheries of the Republic of Indonesia.

Anonymous, (2014). Seawater http: //file.upi.edu/ Directory / FPIPS / JUR._PEND. _GEOGRAFI / $19490205197803 \overline{1-}$

DJAKARIA_M_NUR

AIR_LAUT.pdf. Accessed on October 13, 2015.

Apriadi, D. (2005). Heavy Metal Content of $\mathrm{Hg}, \mathrm{Pb}$ and $\mathrm{Cr}$ in Water, Sediment and green mussels (Perna viridis $I$.) Waterway Kamal Muara, Jakarta Bay. Department of Water Resource Management. Faculty of Fisheries 
and Marine Science, Bogor Agricultural University. Bogor.

Ariasih. (2008). Study on Air Pollution Laundering Beans Koro (Vignaunguicuculata L) in Irrigation Timuhun Nyanglan Desa Klungkung regency.

Arikunto, \& Suharsimi. (2006). Research Procedure A Practical Approach. Rineka Reserved. Jakarta.

Arielle, R. N. (2011). Content Relationships Lead $(\mathrm{Pb})$ in water with oyster meat (Crasosstrea cucullata) in the Port of Coastal Fisheries Mayangan Probolinggo, East Java. Skripsi. UNIBRAW. Malang.

BSN (National Standardization Body). (2009a). SIN 7387: Limit for Heavy Metal Contamination in Food. BSN, Jakarta. $25 \mathrm{p}$.

Darmono. (2001). Environment and Pencemaran. Jakarta: PRESS UI.

Eastaugh, B., \& Chris, S. J. (2008). Aspects of Aquaculture Production pearl oysters. http: //www.ikan mania.com/category/bisnis/mutiara/.

Effendi, E. (2010). Proceedings Applications Ammonia Solution to Improve sperm motility and fertilization of eggs pearl oysters (Pictada maxima). http://www.dostoc.com/docs/106274 41/bahan-prosiding.

Effendi, H. (2003). The study Water of Quality For Environmental Resources Management and Water. Kanisus. Yogyakarta.

Endrastuti, O. (2014). Pengaruh pH Against Heavy Metal Power Adsorbsi Fe 2+ (iron) by Using Activated Carbon Coal (Thesis). UNIBRAW, Malang.

Faisolhezim. (2014). http://faisolhezim fst12.web.unair.ac.id/artikel_detail109415-Biomonitoring-

Kasuskasus\%20besar\%20pencema ran\%20\%20laut.html. Diakses on May 12, 2015.

Hasbi, R. (2007). Analysis of Pollutants Metals Copper $(\mathrm{Cu})$ and lead $(\mathrm{Pb})$ in Marine Sediments Port Pantoloan by depth (Thesis). UNTAD Press, Palu.

Ika, Tahril \& Said, I. (2012). Analysis of Metals Lead $(\mathrm{Pb})$ and iron $(\mathrm{Fe})$ in Sea Water Coastal District of Palu Taipa Ferry Pelanuhan Utara. Jurnal. Tadulako. Palu.

Irianto, A., Sipatuharda, D., Antara, A. (1994). Observation oyster Crassostrea spp. Tanjung Pinang and Bintan waters,
Balitdita Riau. Warta Islands, 6(1), 19-21.

Khasanah, N. E. (2009). Adsorption of metal berat. Jurnal Oseana, 34(4), 1-7.

Mansyur, K. (2000). Feasibility Study of Multiple Parameter Physical and Chemical Oceanography in Support Extensification Seaweed Cultivation Gulf Laikan District of Mangarabombang Takalar. Thesis Department of Marine Sciences. Faculty of Marine Sciences and Fisheries. Hasanuddin University. Makassar.

Marzuki, (2002). Metodelogi Research. Yogyakarta: BPE-UII.

Mezei, T. (2010). About Oyster. http: //www.ostrea.org/oysters.html. Accessed on August 31, 2010.

Miller, T. G. (2004). Environmental Sciene: Working with the earth, 10th edition. International Student Edition. Thomson Learning, Inc.

Narbuko \& Ahmadi (2004). Metode Research. Earth Literacy. Jakarta.

Palar, H. (1995). Ekotoksiologi: Pollution and heavy metals. Jakarta: Rineka Reserved.

Pardi, A. (2014). Contents Heavy Metal Lead $(\mathrm{Pb})$ in White Shrimp (Penaeus merguiensis) Based on Place of Fishermen in the Bay of Islands Tanjungpinang Riau. FIKP UMRAH.

Parenrengi, A., Syarifuddin, T., \& Sri, L. (1998). Study type and abundance of plankton at various depths and its relationship with Mabe oysters Food Composition (Pteria penguin). Indonesian Fisheries Research Journal, IV(4). Coastal Fisheries Research Institute Maros. Watampone.

Purnomo, D. (2009). Heavy metals as a contributor to water pollution laut. Di Upload returned from http://masdony.wordpress.com/2009 /04/19/logam-berat-sebagaipenyumbang-pencemaran-air-laut/.

Ricomarsen. (2010). Heavy Metal Intoxication. Marsen's-Opinion and Sciences.htm.com.

Romiandria, (2013). http: // Ecology Perairan.co.id.html. accessed on October 20, 2015.

Romimohtarto, K. (2001). Biologi Laut. About Marine Life Sciences. Publisher Djambatan: Jakarta. 
Romimohtarto, K., \& Juwana, S. (2009). Marine Biology. Djambatan. Jakarta.

Said, I., Jalaluddin, M. N., Upe, A., \& Wahab, A.W. (2009). Penetapan concentrations of heavy metals chromium and lead in the sediment of the river estuaries matangpondo Palu. Jurnal Chemica, 10(2), 40-47.

Sambaz. (2010). Raising oysters Pearl. Zaldibiaksambas.

Files.com/2010/10/tiram-mutiara.pdf.

Sastrosupadi, A. (2000). Rancangan Practical Agriculture Experiment. edisi revisi. Kanisius. Yogyakarta. Hal 70.

Sinaga T. (2009). Diversity macrozoobenthos as an indicator of the quality of the waters of Lake Toba Toba Samosir Balige. Graduate School of the University of North Sumatra: Medan.

Susiati, H., Arman, A, \& Yarianto. (2009). Content of Heavy Metals (Co, Cr, Cs, $\mathrm{As}, \mathrm{Sc}$, and $\mathrm{Fe}$ ) in Sediments in the Coastal Zone I Muria. Jurnal
Peninsula Nuclear Energy

Development, 11(1).

Sham, L. (2004). Analysis of levels of iron $(\mathrm{Fe})$ in Soybean by complexing Fenantrolin. Skripsi. UNTAD Press. Pali.

Syazili, A. (2011). Biologi oysters. http://www.bumi-ilmu.htm.com. Accessed 25 November 2012.

Wibisono M. S. (2010). Introduction of Marine Science. Issue 2. The UI Press. Jakarta.

Wulandari, E., Herath, E. Y, \& Arfiati, D. (2012). Heavy Metal Content of $\mathrm{Pb}$ in Sea Water and oysters (Saccostrea glomerata) as a bio-indicator Water Quality Prigi, Trenggalek, East Java. Journal Fisheries Research, 1(1), 1014. UNIBRAW. Malang.

Zulkifli, E. (2003). Nutrient content of substances in Poros Water and Surface Water Seagrass East Bintan Riau. Natur Indonesia Journal, 5(2), 139-144. 